\title{
EXPLORANDO OS ESPAÇOS VAZIOS: JAZZ E ESTRUTURA ORGANIZACIONAL
}

\author{
Mary Jo Hatch \\ Professora da McIntire School of Commerce (University of Virginia). \\ E-mail: mjhatch@virginia.edu
}

\begin{abstract}
RESUMO
Este artigo utiliza-se do jazz como um veículo metafórico para redescrever o conceito de estrutura organizacional de forma adequada ao vocabulário emergente dos estudos organizacionais. É apresentada uma descrição de alguns elementos básicos da performance do jazz - solo, acompanhamento, trading fours, pergunta e resposta, groove e sensibilidade -, sustentando a redescrição da estrutura organizacional como sendo ambígua, emocional e temporal. De maneira reflexiva, o artigo não somente demonstra os conceitos aos quais se refere, mas apresenta uma performance, a exemplo do jazz, do método de Rorty da redescrição por meio da metáfora.
\end{abstract}

\begin{abstract}
This paper uses jazz as a metaphoric vehicle for redescribing the concept of organizational structure in ways that fit within the emerging vocabulary of organization studies. The metaphoric comparison begins with a description of some basic elements of jazz performance - soloing, comping, trading fours, listening and responding, groove and feel - and builds on those to redescribe organizational structure as ambiguous, emotional, and temporal. In reflexive fashion, this concept is not only demonstrated, but a jazz-like performance of Rorty's method of redescription via metaphor is presented.
\end{abstract}

\section{PALAVRAS-CHAVE}

Estrutura organizacional, estudos organizacionais, jazz, metáfora, criatividade.

\author{
KEY WORDS
}

Organizational structure, organization studies, jazz, metaphor, creativity. 


\section{INTRODUÇÃO}

À medida que os negócios tornam-se mais adaptáveis e flexíveis como resposta às constantes variações de demanda e oportunidades em seus mercados globalizantes, os entendimentos tradicionais da estrutura organizacional vão-se esgotando. Primeiramente, esse esgotamento foi descrito em termos de organogramas; os relacionamentos eram multidimensionais demais para serem representados em um quadro bidimensional ou mudavam com tanta frequiência que fazer um organograma passou a perder o sentido. Quando as velhas noções estruturais entraram em colapso, essa mudança foi comunicada em termos como outsourcing, de-layering, de-differentiation e reengenharia. Agora, conceitos como redes e organizações virtuais estão desafiando as noções tradicionais da própria organização. Todavia, tal qual uma estrela colapsante que forma um buraco negro, a noção de colapso da estrutura organizacional não desaparece. Sua ausência é sentida como um espaço vazio que atrai. Por exemplo, alguns membros de organizações falam de uma frustrante e perpétua falta de comunicação e coordenação e de uma proporcional perda de controle e identidade; alguns chegam até a se tornar nostálgicos e personificar sua sensação de vazio no "líder ausente". Outros vivenciam esse espaço vazio em termos de liberdade para criar algo novo.

Quando um conceito como estrutura organizacional não mais se ajusta aos nossos propósitos descritivos ou analíticos (por ser muito estático para nos ajudar a entender as organizações descritas em termos como "adaptáveis", "flexíveis" e "virtuais"), é geralmente aceitável substituí-lo por outro conceito, mais bem formulado. O problema é, pelo menos atualmente, que ainda não surgiu nada melhor. De fato, o trabalho de Rorty (1989) sugere a sabedoria de admitir que a busca por um conjunto final de conceitos não tem fim. Assim, no lugar disso, Rorty defende a redescrição, uma reciclagem constante de conceitos antigos com a utilização de uma linguagem nova, contraditória até, visando a substituir um vocabulário desgastado por um novo. Nas palavras de Rorty (1989):

"O método é redescrever muitas e muitas coisas de maneiras diferentes, até criar um padrão de comportamento lingüístico que fará com que a nova geração seja atraída a adotá-lo, fazendo, assim, com que eles busquem novas e adequadas formas de comportamento não-lingüístico, por exemplo, a adoção de novos equipamentos científicos ou novas instituições sociais."

Rorty (1989, p. 9) ainda explica que o método não envolve uma luta contra os vocabulários antigos, mas sim uma tentativa de "fazer com que o vocabulário de minha preferência pareça atraente, mostrando como ele pode ser usado para descrever uma variedade de tópi- cos". Apesar de Rorty focar no que a redescrição implica para a emergência de um novo tipo de ser humano (o ironista liberal), somente tomarei seu método emprestado para reciclar o conceito de estrutura organizacional de forma a se adequar ao vocabulário emergente mencionado no parágrafo de abertura. Para tanto, usarei a metáfora, sugerida por Rorty (seguindo Hesse, 1980 e Davidson, 1984) como um veículo para a redescrição.

É importante reconhecer que de maneira alguma sou a primeira pessoa a tentar reconceitualizar a estrutura organizacional (e provavelmente não serei a última). A tentativa mais influente neste sentido até o momento foi feita por Anthony Giddens e seus seguidores, que propuseram e desenvolveram a teoria da estruturação (Giddens 1979, 1984; Ranson et al., 1980; Pettigrew, 1987; Reed, 1997). Entretanto, seu trabalho se mantém firmemente enraizado no vocabulário "antigo" da sociologia moderna e da teoria organizacional, enquanto eu tentarei posicionar a estrutura organizacional em um vocabulário emergente, algumas vezes ligado à teoria pós-moderna (Cooper e Burrell, 1988; Gergen, 1992; Hassard, 1996a). Apesar de haver pontos de ligação que podem ser estabelecidos entre a teoria da estruturação e a abordagem metafórica, deixo essas comparações para considerações futuras, as quais mencionarei na conclusão.

Seguindo Rorty, usarei a abordagem metafórica. Morgan (1986) sugere que a metáfora engaja e envolve uma base de vivência mais ampla do que qualquer outra abordagem à teorização, no sentido que a metáfora trabalha com a imaginação do teórico em sua totalidade. Isto é, a metáfora não funciona simplesmente no âmbito analítico da imaginação (no qual Giddens e seus seguidores enfocam), mas convoca, também, capacidades emocionais e estéticas. Rorty (1989, p. 17) explica como a metáfora contribui para o vocabulário emergente:

“(...) precisamos ver a distinção entre o literal e o metafórico do modo como Davidson a vê: não como uma distinção entre dois tipos de significado, nem ao menos entre dois tipos de interpretação, mas como uma distinção entre usos comuns e incomuns de sons e sinais gráficos (palavras). Os usos literais de sons e sinais gráficos são aqueles com os quais podemos lidar com nossas velhas teorias (...) Seu uso metafórico é do tipo que nos mantém ocupados no desenvolvimento de uma nova teoria."

Neste artigo, utilizo o jazz ou, mais especificamente, a performance de jazz improvisacional, como uma metáfora, talvez inusitada, mas mesmo assim valiosa, para redescrever a estrutura organizacional. Essa metáfora parece ser tão improvável porque o jazz é mais freqüentemente visto por sua falta de estrutura, mas é justamente esse paradoxo que sugere a metáfora do jazz como uma ferramenta valiosa para a redescrição. Isto 
é, o relacionamento difícil entre a estrutura, o jazz e os músicos é que faz dessa metáfora ao mesmo tempo incomum e promissora no contexto do vocabulário emergente que se propõe construir por meio da redescrição. Digo isso porque contradição, paradoxo e questionamento das superestruturas como agentes totalizadores são todos parte de uma teoria organizacional pós-moderna que constantemente contribui para o vocabulário emergente dos estudos organizacionais (Reed e Hughes, 1992; Hassard e Parker, 1993; Boje et al., 1996; Burrell, 1997).

Como o uso da metáfora encaixa-se aqui na noção de Rorty de redescrição em vez de descrição, peço ao leitor que tenha em mente que não estou tentando sugerir que $j a z z$ e organização são equivalentes. Minha tese defende que conduzir a estrutura organizacional ao longo das diretrizes sugeridas pelos jazzistas na orientação das estruturas na execução do jazz pode ajudar-nos a gerar uma redescrição da estrutura organizacional compatível com o vocabulário emergente dos estudos organizacionais. Assim, o presente uso da metáfora do jazz para redescrever a estrutura organizacional é orientada para a performance e a execução; convocando o engajamento, ou melhor, o reengajamento, com as práticas e os processos organizacionais, como será explicado abaixo. Ademais, em virtude de minha abordagem ser pragmática/hermenêutica e não analítica, isso deverá ser demonstrado, em vez de explicado. Assim, neste artigo, evocarei o que entendo por uma apreciação da estrutura no estilo do jazz para, então, transferir essa apreciação, pela redescrição metafórica, ao conceito da estrutura organizacional. Para tanto, tentarei fazer com que a redescrição "pareça atraente", mostrando como ela se relaciona a uma variedade de tópicos, incluindo ambigüidade, emoção e andamento, todos parte do vocabulário emergente dos estudos organizacionais e, para cada um deles, eu sustento, a metáfora do jazz tem uma contribuição imaginativa a fazer.

\section{ALL THAT JAZZ}

Há muitos aspectos do jazz. Nesta seção, descreverei somente aqueles que considero que se destacam como sendo diretamente relacionados à estrutura, tanto na teoria do jazz como no contexto da história da performance do jazz. O material sobre jazz apresentado abaixo resulta de uma combinação de três fontes. Primeiro, sou casada com um jazzista (baterista e compositor) e muito do meu entendimento sobre o jazz foi formulado enquanto eu ouvia e assistia a performances de jazz e conversava com os músicos antes e depois dos ensaios e das turnês de meu marido. Segundo, e como um efeito direto do primeiro, tive o privilégio de ter a tutela do mestre de jazz dinamarquês Per
Goldschmidt, cuja longa exposição à sociologia organizacional (seu pai e padrasto eram ambos sociólogos) fizeram com que sua fonte de conhecimento sobre o jazz fosse mais facilmente acessível para mim. Terceiro, o rico desenvolvimento da metáfora da improvisação nos estudos organizacionais (Bastien e Hostager, 1988, 1992; Weick, 1989, 1993, 1998; Eisenberg, 1990; Crossan e Sorrenti, 1997; Hatch, 1997; Barrett, s.d.), bem como a extensa literatura sobre jazz (especialmente Berliner, 1994), forneceram o suporte e a inspiração para os pontos que desenvolverei abaixo.

\section{A METÁFORA NÃO FUNCIONA}

SIMPLESMENTE NO ÂMBITO

\section{ANALÍTICO DA IMAGINAÇÃO MAS CONVOCA, TAMBÉM, CAPACIDADES EMOCIONAIS E ESTÉTICAS.}

Reconheço que muitos leitores podem vir a ter conhecimentos limitados sobre o jazz, de forma que o jazz deve se descrito com detalhes suficientes para permitir a redescrição da estrutura organizacional utilizando seus termos. Aqueles leitores que já atuaram como jazzistas podem considerar minhas descrições desnecessariamente cansativas e, ao mesmo tempo, incompletas. Reconheço que tentativas de descrever o que é amplamente de conhecimento tácito são insatisfatórias quando comparadas com a experiência real. Todavia, acredito ter conseguido muito insight e entendimento dessa metáfora sem o benefício de tocar, de fato, o jazz. Como muitos leitores estarão, provavelmente, em situação parecida, minhas descrições visam a compartilhar com eles meu entendimento e o potencial dessa metáfora. Se você toca $j a z z$, você pode desenvolver essa metáfora por si só; meus comentários aqui são simplesmente oferecidos para inspirá-lo a fazê-lo.

\section{A ESTRUTURA NO JAZZ}

A estrutura do jazz fornece a matéria-prima para a improvisação pelos jazzistas. A improvisação, por sua vez, constitui a característica distintiva do jazz. Em outras palavras, o jazz distingue-se de outros gêneros musicais, seja a música clássica ou o rock, por seu uso improvisacional da estrutura. Como desenvolverei abaixo, os jazzistas servem-se da estrutura de formas criativas, que permitem com que eles alterem as bases estruturais de sua performance. Meu desenvolvimento da metáfora do jazz trará à tona essa qualidade paradoxal, 
junto com alguns outros pontos que irei, então, relacionar ao vocabulário emergente dos estudos organizacionais. Para tanto, precisaremos começar por alguns fundamentos.

\section{TEMAS, COMPOSIÇÕES E IMPROVISAÇÃO}

As performances de jazz são estruturadas ao redor de composições que são, por sua vez, estruturadas, de forma solta, por arranjos musicais parciais chamados temas. O tema de uma composição define, pelo menos, uma seqüência de acordes, uma idéia melódica básica e, normalmente, um andamento aproximado. Os músicos de jazz podem tocar um tema em qualquer clave, usando uma variedade de ritmos e harmonias alteradas que eles introduzem enquanto tocam a composição. A improvisação se faz ao redor do tema, que normalmente é tocado "direto" (sem muitos adornos improvisacionais) no começo da composição, depois passa por improvisações e, finalmente, é retomado e tocado novamente como a conclusão. O tema é apresentado na composição sugerindo um ritmo, uma harmonia e uma melodia particulares. A composição é, então, trabalhada deste ponto de partida por meio da improvisação, na qual diferentes interpretações da idéia inicial são oferecidas e novas idéias e outras interpretações podem ser exploradas.

Apesar do tema ser normalmente tocado explicitamente somente no começo e no fim de uma composição, a estrutura contida no tema é implicitamente mantida o tempo todo. Para entender como isso funciona, cantarole a melodia do tema repetidamente ao longo da composição e você imediatamente reconhecerá sua presença na forma como os músicos improvisam em sua ausência. De fato, os jazzistas muitas vezes mantêm o tema em suas cabeças (isto é, em sua imaginação auditiva) enquanto tocam e o usam não somente como um foco improvisacional, mas para se orientarem em relação a sua posição temporal, harmônica e melódica na música.

\section{SOLO, ACOMPANHAMENTO E FOURS}

O solo proporciona um mecanismo para que um determinado músico tome a liderança na introdução de novas idéias que são desenvolvidas ao longo da composição depois de ter sido tocado o tema. Essa função é passada pelos artistas (algumas vezes a ordem do solo é combinada antecipadamente, em outras é trabalhada à medida que os músicos tocam). Enquanto um músico faz o solo, os outros podem acompanhá-lo, oferecendo uma base rítmica e harmônica para a improvisação do solista e ocasionalmente alimentando o solista com idéias que podem ou não ser incorporadas ao solo.
Os solistas encorajam a troca de idéias ao deixarem espaço em sua atuação para outros músicos fazerem sugestões; por exemplo, eles podem deixar lacunas entre suas frases melódicas ou tocar seus acordes ambiguamente excluindo certas notas que distinguiriam um acorde de um ou dois outros acordes. Naturalmente, eles não pensam explicitamente: "Tudo bem, agora vou deixar um espaço para alguém preencher". Lacunas e preenchimentos são mais espontâneos do que isso. Os músicos ouvem a atuação dos outros e, nesse processo, espaços são criados e preenchidos por uma lógica que emerge como parte da interação entre eles. Esse processo de ouvir e tocar simultaneamente produz o dar e receber característicos de uma improvisação de jazz ao vivo e também possibilita as condições para um conflito que pode introduzir o inesperado, inspirando a excelência no desempenho, mas, ao mesmo tempo, arriscando um desastre.

A troca de funções entre os solistas e aqueles que acompanham pode, talvez, ser vista mais claramente em uma prática conhecida como trading, taking ou swapping fours (ou simplesmente fours), algumas vezes indicada no palco por um dos músicos levantando quatro dedos. No fours, os músicos se revezam em solos em compasso quaternário numa rápida sucessão (normalmente o baterista assume quatro compassos entre cada um dos outros músicos), criando uma intensa troca de sons e idéias musicais.

\section{PERGUNTA E RESPOSTA}

Ouvir tem uma importante função no jazz improvisacional. Essa importância vem do fato da abertura da estrutura no jazz (sutileza, subentendido e ambigüidade) significar que a previsibilidade da atuação dos outros se mantém em um nível mínimo e que as chances de conflito (desarmonias indesejáveis, discordância rítmica) são extremamente altas. Entretanto, em vez de restringir ou mesmo impedir um bom desempenho, esses conflitos podem desafiar os músicos a construírem um sentido com base em padrões inesperados de sons. Jazzistas experientes sabem que os erros são definidos pelo contexto, então, se alguém tocar uma nota "errada", a alteração do contexto pode salvar a situação e, na melhor das hipóteses, produzir uma idéia inusitada. A incorporação do inesperado é essencial para uma boa improvisação no jazz. Naturalmente, à medida que os jazzistas vão adquirindo mais experiência, sua capacidade de antecipar os movimentos dos outros aumenta junto com sua habilidade de reagir a movimentos inesperados. Frustar as expectativas antecipadas daqueles com quem se toca torna-se um mecanismo importante para manter o jazz "vivo".

De maneira ideal, cada músico ouve todos os outros músicos no momento em que estão tocando uma 
composição. Todavia, muitos admitem sem restrições que somente alcançam esse ideal uma vez ou outra, principalmente quando atingem momentos de pico na performance do jazz. Em outros momentos, concentram-se em ouvir intensamente um ou dois outros músicos, muitas vezes mudando o enfoque de um a outro ao longo do desenvolvimento da composição. Assim, em qualquer composição, a probabilidade é que pelo menos alguém está ouvindo e respondendo a cada um dos músicos que contribuem. Naturalmente, um músico irá ouvir e responder melhor se ele observar como os outros estão ouvindo e respondendo a ele. Como todos os outros fatores mantidos constantes, quanto maior a interpenetração dos processos de ouvir e responder, tanto melhor a música soará, e é essa interpenetração auditiva que, em parte, estrutura a performance de uma composição.

\section{GROOVE E SENSIBILIDADE}

Se uma banda for atingir o desempenho máximo em uma determinada composição, os músicos encontrarão o groove (seqüência rítmica e harmônica com muito balanço, geralmente referindo-se à dupla baixo e bateria). Diz-se que uma performance de jazz está "in the groove" quando o jazz é bem tocado e, portanto, muito satisfatório. O groove ajuda os músicos a tocarem juntos e a manterem em mente a posição das notas e modulações permitindo-lhes sentir internamente a estrutura da composição, um requisito para que eles saiam dos padrões previsíveis. Por exemplo, ritmicamente, o groove envolve coordenação, significando que os músicos (especialmente o baterista e o baixista) concordem com o posicionamento da batida. Uma vez que o groove é encontrado, o baterista ou o baixista podem tocar à frente, ou atrás, da batida para criar uma tensão, tanto adiantando a composição como atrasando-a, mesmo que sutilmente. Sem uma grande noção do groove, a prática de tocar antes ou depois da batida levaria ao adiantamento ou ao retardamento, mas com o groove essa prática amplifica o conteúdo emocional da performance e ajuda a dar à música um sentimento distintivo (que, neste caso, se deve ao posicionamento relativo das notas).

Os jazzistas usam a sensibilidade não somente em conjunção com o ritmo, mas também em relação às estruturas melódica e harmônica do jazz. Por exemplo, a altura do som, o timbre e a melodia podem criar tensão e alívio independentemente do processo de tocar à frente ou atrás da batida ou em combinação com esse processo. Além disso, o contexto - como os músicos e seu público se relacionam uns com os outros e a situação em que eles estão no momento em que a composição é tocada - contribui para que se sinta uma composição de uma maneira diferente a cada vez que ela é tocada. Juntos, groove e sensibilidade têm forte influência na aparência emocional e estética do som e encorajam a platéia a contribuir para a música ao sentir o que os músicos sentem. Quando o groove e a sensibilidade estão plenamente incorporados (criando uma música que toca o ouvinte literal e fisicamente), um senso de comunhão ocorre entre os presentes (tanto fisicamente presentes, como no sentido de estarem conscientes do que ocorre, isto é, ouvindo).

\section{O JAZZ E O VOCABULÁRIO EMERGENTE DOS ESTUDOS ORGANIZACIONAIS}

O Quadro 1 resume os pontos básicos sobre o jazz apresentados até o momento e oferece alguns paralelos com o vocabulário emergente dos estudos organizacionais. Por exemplo, o desenvolvimento da capacidade de fazer trocas entre as funções de liderança e de apoio é uma habilidade associada com um trabalho bem-sucedido de equipe e colaboração. A metáfora do jazz sugere ouvir em qualquer função, solo, acompanhamento e trading fours, nas interações rotineiras entre os membros da equipe e talvez avaliar até que ponto essas funções são adequadamente realizadas e se as trocas entre elas estão ocorrendo facilmente. Por exemplo: os solos são interessantes? Aqueles que fornecem o acompanhamento estão contribuindo para as

\section{Quadro 1 - Paralelos entre o jazz e o vocabulário emergente dos estudos organizacionais}

\begin{tabular}{|c|c|c|}
\hline Jazz & Descrições & Vocabulário emergente \\
\hline $\begin{array}{l}\text { Solo } \\
\text { Acompanhamento } \\
\text { Trading fours }\end{array}$ & $\begin{array}{l}\text { Assumir a liderança. } \\
\text { Dar apoio à liderança dos outros. } \\
\text { Fazer trocas entre funções de liderança e de apoio. }\end{array}$ & $\begin{array}{l}\text { Trabalho em equipe } \\
\text { Colaboração }\end{array}$ \\
\hline $\begin{array}{l}\text { Pergunta } \\
\text { Resposta }\end{array}$ & $\begin{array}{l}\text { Abrir espaço para as idéias dos outros. } \\
\text { Responder às idéias dos outros e acomodá-las. }\end{array}$ & $\begin{array}{l}\text { Construção do sentido } \\
\text { Processo estratégico }\end{array}$ \\
\hline Groove e sensibilidade & $\begin{array}{l}\text { Tensão e alívio emocionais. } \\
\text { Ressonância do som incorporado. } \\
\text { Comunhão entre músico e platéia. }\end{array}$ & $\begin{array}{l}\text { Cultura e identidade } \\
\text { organizacionais }\end{array}$ \\
\hline
\end{tabular}


idéias do solista ou estão interferindo na habilidade do solista de se expressar? Os membros sabem quando assumir um solo? Eles sabem quando e como terminar um solo? Esses pontos podem ser mais elaborados com o uso dos conceitos de pergunta e resposta. As interações entre os membros da organização estão abertas a novas idéias e oportunidades para acomodá-las? Essas questões são estreitamente associadas com como se faz o sentido em organizações (Weick, 1995) e podem ser relacionadas de forma útil ao organizational talk (Boden, 1994) e ao processo estratégico (Mintzberg et al., 1976; Pettigrew e Whipp, 1991). Da mesma forma, o groove e a sensibilidade alinham-se com a cultura e a identidade organizacionais em suas ênfases similares nos aspectos emocionais e estéticos da vida organizacional (Alvesson, 1990; Gagliardi, 1990, 1996; Hatch, 1993; Schultz, 1992; Hatch e Schultz, 1997).

\section{O JAZZ DISTINGUE-SE DE OUTROS}

\section{GÊNEROS MUSICAIS, SEJA A MÚSICA CLÁSSICA OU O ROCK, POR SEU USO} IMPROVISACIONAL DA ESTRUTURA.

Apesar de simples analogias aos interesses correntes nos estudos organizacionais colocarem a metáfora do jazz. em um relacionamento paralelo com o vocabulário emergente dos estudos organizacionais, buscamos muito mais insight e envolvimento de uma abordagem metafórica do que esse simples conjunto de novos termos pode oferecer. Para que tenha valor, a metáfora do jazz deve fazer uma contribuição original para o nosso entendimento. Nos termos de Rorty, a metáfora deve revisar substancialmente nosso vocabulário atual e as descrições que nele se baseiam. Pode a metáfora do jazz conseguir isso? Acredito que pode, ou que podemos, por meio da metáfora do jazz, como tentarei demonstrar abaixo.

Todavia, antes de sairmos do nível da simples analogia, é preciso salientar que o processo de redescrição já começou. Por exemplo, observe a primeira coluna da tabela e note a ênfase no envolvimento sensório e sensual que permeia a metáfora do jazz. O ato de ouvir é naturalmente relacionado ao ato de escutar, mas a musicalidade de todos os aspectos da metáfora vai muito mais além, convidando-nos a escutar e a sentir a organização, a ouvir e nos emocionar com seus ritmos, harmonias e melodias. Isso se faz em contraste com as abordagens anteriores à estrutura organizacional, que, geralmente, não são sensoriais, mas sim analíticas, orientando nossas mentes a aspectos da organização, mas normalmente não envolvendo nossos corpos nem suas capacidades sensórias. A metáfora do jazz nos estimula a pensar sobre a estrutura organizacional com nossos ouvidos e a envolver nossos corpos e emoções no processo. Esse envolvimento sensório e emocional se relaciona a outra característica importante do jazz - ele é tocado. O jazz acontece. É uma atividade, não simplesmente uma categoria abstrata. Como uma atividade, o jazz é algo no qual se entra, se participa, se vive. Por meio da metáfora do jazz, a organização pode também ser imaginada como uma atividade na qual se entra, se participa e se vive, e essa metáfora nos estimula a fazê-lo. Quando estamos envolvidos dessa forma, imaginar a estrutura organizacional nos transporta ao âmbito da atividade. Neste ponto, encontramos uma outra similaridade aos estudos organizacionais - o jazz baseia-se na performance. Assim, a metáfora do jazz orienta as interpretações organizacionais tradicionais a novas direções pela sugestão de que a estrutura organizacional deveria ser redescrita em termos de execução e performance (isto é, a estrutura não como um estado ou resultado, mas como um conjunto de práticas ou processos de execução). Para desenvolver os aspectos de execução e performance da metáfora do jazz, prossigamos analisando como os músicos usam suas estruturas quando tocam o jazz.

\section{COMO OS JAZZISTAS USAM SUAS ESTRUTURAS: OS ESPAÇOS VAZIOS DO JAZZ}

Se quiséssemos apreciar a estrutura organizacional da mesma forma como apreciamos o jazz, por onde começaríamos? Acredito que a chave para a redescrição metafórica usando o jazz como veículo reside na apropriação das formas nas quais os jazzistas se orientam em relação às suas estruturas e das formas como as utilizam. Observe que já estou além da pergunta comum “qual estrutura devemos usar/usamos?", enfocando, em vez disso, a questão "como devemos usar/usamos nossa estrutura?". Este é um movimento lingüístico importante, porque retira a estrutura do âmbito dos estados de ser e a posiciona como uma parte do processo de transformação. Essa nova orientação nos convida à atividade $\mathrm{e}$ constitui o engajamento ou, para usar termos mais voltados à performance, ela ativa e engaja. Em termos mais gerais, em vez de tentar expressar suas estruturas explicitamente, os jazzistas constroem constantemente a estrutura implícita e descobrem que são capazes de expressá-la - é uma estrutura que apóia, mas não especifica. Por exemplo, como vimos acima, encontrar o groove permite aos músicos internalizar as estruturas rítmica, harmônica e melódica de uma composição, o que os livra de ter de tocar explicitamente. Não tocar o tema, enquanto se improvisa sobre ele, é um outro exemplo de como a estrutura do jazz é implícita. 
É importante compreender que os jazzistas não precisam, ou nem mesmo querem, tocar suas estruturas explicitamente. Por exemplo, eles evitam tocar o acento na primeira nota do compasso, especialmente quando se trata do primeiro movimento do primeiro compasso de uma seção musical. E isso apesar do fato de, se não souberem onde acento está, ficariam perdidos e seria impossível tocarem juntos (esta é uma condição comum para um "crash" ou "trainwreck", em que os músicos interferem de tal forma uns com os outros que não conseguem continuar a tocar a composição ou, mesmo se fossem capazes de disfarçar e continuar tocando, a composição seria considerada um desastre de acordo com todo e qualquer critério para um performance aceitável de jazz).

Da mesma forma, os jazzistas não aceitam suas estruturas como dadas. Eles acreditam que a atitude adequada em relação à estrutura é descobrir o que se pode tirar dela. Assim, interpretam suas estruturas da forma mais aberta possível, maximizando a ambigüidade e o potencial para a multiplicidade interpretativa. Muito dessa abertura atribuída ao jazz resulta da orientação em relação à estrutura. A impressão errônea de que o jazz é simplesmente "feito à medida que é tocado" é resultado da liberdade possibilitada por estruturas implícitas (isto é, a estrutura que não é tocada explicitamente, mas mesmo assim se faz presente nas mentes, emoções e corpos dos músicos). A liberdade resultante de não ter de tocar explicitamente as características estruturais significa que o músico pode tocar em torno delas, o que estimula a criatividade (Eisenberg, 1990). Isto é, não tocar as estruturas cria um espaço para improvisar, o que produz a atitude inovadora que, de acordo com teóricos da criatividade, provoca a imaginação criativa (Adams, 1990). Isso também inspira inovação e mudança. Em termos de jazz, entretanto, note como essa atitude inovadora implica usar a estrutura para transportar-se além dela.

Para percebermos isso mais claramente, precisamos sair do âmbito de como uma composição de jazz é tocada e assumir uma perspectiva mais ampla de como o jazz evoluiu no decorrer da história. Como me foi explicado por Per Goldschmidt, o jazz nasceu com o ragtime no final do século XIX e de lá se transformou no estilo de Nova Orleans, no swing e no be-bop, no jazz moderno e no free jazz. Se analisarmos a história desses estilos de jazz, perceberemos uma seqüência na qual a estrutura de um período anterior é repetidamente retomada, e os músicos, ao tentar expressar algo novo, exploram cada vez mais as estruturas familiares do passado e estilos do momento, até que algo reconhecidamente diferente emerge.

Tomemos o exemplo do ritmo. Ritmicamente, a música tradicional européia é tocada na primeira e terceira batidas de um compasso de quatro tempos, enquan- to o ragtime enfatiza a segunda e quarta batidas do compasso. À medida que a ênfase passa de 1 e 3 para 2 e 4 , obtemos o ritmo no estilo do ragtime, ou do jazz. Conforme o jazz se desenvolveu por esse caminho, os músicos começaram a tocar ritmos entre todos os quatro tempos, alterando o ritmo que originalmente era de quatro semínimas para um que dava a sensação de colcheias (usando, por exemplo, quiálteras), ou mesmo semicolcheias, primeiro nos proporcionando os estilos dixieland e swing e, mais tarde, o be-bop e o jazz moderno. Um processo similar ocorreu harmonicamente.

\section{A INCORPORAÇÃO DO \\ INESPERADO É ESSENCIAL}

\section{PARA UMA BOA \\ IMPROVISAÇÃO NO JAZZ.}

Em cada fase estilística do desenvolvimento, os jazzistas tocaram fora de estruturas harmônicas familiares até que se distanciavam tanto que alguma outra estrutura precisou ser criada. Críticos e outros comentadores de jazz interpretaram essas mudanças rítmicas e harmônicas como novos estilos reconhecíveis, que rotularam como o estilo de Nova Orleans, o swing, o be-bop e o jazz moderno, até que, com o free jazz, a estrutura tornou-se tão sutil a ponto de ser praticamente indetectável a qualquer um que não fosse um ouvinte sofisticado, incluindo muitos jazzistas tradicionais. De fato, alguns vêem o free jazz como uma tentativa de tocar sem nenhuma estrutura, apesar de mesmo os músicos mais familiarizados com o estilo do free jazz precisarem de alguma estrutura para se orientarem em relação uns aos outros na composição.

Para inserir essa visão histórica em termos processuais, conforme cada uso da estrutura é desafiado pelo processo de tocar fora ou entre as notas, harmonias e batidas previstas em uma forma existente, novas formas de jazz são criadas, redefinindo as expectativas e apresentando, assim, novas oportunidades (novos espaços vazios) para se opor às primeiras. Assim, as práticas do jazz (solo, acompanhamento, trading fours, pergunta e resposta, encontrar o groove, tocar o tema, improvisação) preenchem os espaços vazios da estrutura e, quando isso ocorre, a própria estrutura do jazz é transformada. Posto de outra forma, as práticas improvisacionais do jazz constituem as condições para a sua própria transformação estrutural, apesar de serem as próprias estruturas o ponto de partida para a transformação. Assim, tocar o que não é explicado por uma estrutura permite a criação de outra, não exatamente sem nenhuma relação com a primeira, mas, ao 
mesmo tempo, demonstrando tanto continuidade quanto descontinuidade em relação a esta. Em outras palavras, a estrutura utilizada de forma improvisacional causa uma inovação que altera radicalmente as concepções sobre o que a estrutura "é", tanto no sentido material quanto no ontológico.

Os jazzistas não utilizam a estrutura simplesmente para se organizarem. Eles tocam suas estruturas implicitamente, de forma a não expô-las de modo explícito e, ao fazê-lo, tocam suas estruturas no sentido duplo de interação e de alteração das mesmas por meio da improvisação. Transferindo a estrutura para uma base voltada à performance (tocá-la de uma forma interativa), os jazzistas são capazes de alterar radicalmente suas estruturas no sentido histórico de criação de uma descontinuidade com o passado, mas eles o fazem somente pela construção da continuidade com o passado, que se expressa como a estrutura que eles não tocam. A continuidade em suas cabeças (a estrutura da composição) inspira a descontinuidade em seus lábios e dedos (improvisação) conforme eles vão transformando o jazz em um idioma de expressão musical.

Em suma, a estrutura não é sagrada para um músico de jazz, mas é utilizada para sua própria alteração. Assim, ela não é estática, mas sim dinâmica, e, neste sentido, possui um relacionamento complexo com o tempo, sendo simultaneamente contínua e descontínua com o passado. Ademais, da forma como os jazzistas a utilizam, ela é sutil e implícita, exceto no acompanhamento silencioso ao que é efetivamente tocado; ela existe mais como uma ausência do que como uma presença.

Além disso, para o músico de jazz, a estrutura é aberta a interpretações e freqüentemente ambígua, o que significa que, em qualquer momento, uma composição pode ser orientada para múltiplas direções; as direções nas quais ela será levada são decididas somente no momento da performance e serão redeterminadas apenas no momento em que a composição for tocada. Finalmente, a estrutura possui qualidades emocionais que permitem que os músicos e sua platéia se comuniquem fora da consciência intelectual, como por meio do groove e da sensibilidade. Assim, uma visão orientada pelo jazz é uma visão na qual a estrutura possui características emocionais, temporais e de ambigüidade, qualidades prováveis de serem encontradas na ausência de estrutura (isto é, em seus espaços vazios) e em sua presença. Todos esses pontos podem ser identificados no vocabulário emergente dos estudos organizacionais, que, por incrível que pareça, "descobriu" esses mesmo pontos por meio de um processo muito parecido com o do jazz, atuando nos espaços vazios da teoria organizacional, como será demonstrado a seguir.

\section{OS ESPAÇOS VAZIOS DA ORGANIZAÇÃO: REDESCREVENDO AS ESTRUTURAS ORGANIZACIONAIS EM SINTONIA COM A METÁFORA DO JAZZ}

E se considerarmos a estrutura organizacional como sendo ambígua, emocional e temporal (ou temporária)? Recentemente, explorações em, e de, organizações partiram separadamente de cada um desses caminhos. Considerando que certamente há diferenças entre essas linhas de pesquisa, relacionarei cada uma delas, por meio da metáfora do jazz, ao conceito de estrutura organizacional da forma como recomendaria que fosse redescrita. Faço isso para relacionar a redescrição da estrutura organizacional oferecida pela metáfora do jazz com o vocabulário emergente dos estudos organizacionais e para demonstrar, mais adiante, sua ressonância mútua. Esta seção do artigo refere-se às questões: Como poderia soar uma orientação ao jazz em relação às estruturas organizacionais? Como podemos nos relacionar com nossas estruturas organizacionais como os jazzistas se relacionam com as deles?

\section{A AMBIGÜIDADE DA ESTRUTURA}

Como foi explicado acima, os espaços vazios da estrutura de uma composição produzem ambigüidade. Essa abertura (ou falta de fechamento) na estrutura permite que qualquer um dos músicos conduza a composição em uma variedade de direções que, se bem tocadas, contribuem com inovação para a história do jazz e criam uma satisfação momentânea tanto para os músicos quanto para sua platéia. Nessa visão baseada no $j a z z$, a estruturação ocorre no que não é especificado, no sentido em que o não-especificado é uma ambigüidade que pode ser interpretada de forma criativa para produzir inovação. No jazz, a ambigüidade não explica nada, ela é uma parte da estrutura das composições e sua função reside em permitir que os músicos de jazz atuem de maneira criativa. Apesar da ambigüidade nas estruturas de uma composição poder ser interpretada de maneiras que fazem com que os músicos entrem em conflito uns com os outros, esse conflito não é visto como um prejuízo ao desafio, mas sim como um convite à reinterpretação do contexto dentro do qual uma significação é construída.

$\mathrm{Na}$ teoria organizacional, a ambigüidade foi primeiramente conceitualizada em relação à escolha e à tomada de decisões organizacionais. A teoria de March e Olsen (1976) sobre a ambigüidade organizacional especificava quatro formas: a ambigüidade de intenção (preferências mal definidas ou metas múltiplas e conflitantes), a ambigüidade de entendimento (interpretações múltiplas de intenções e feedback), a ambigüida- 
de da história (dificuldade de entender o que aconteceu e porque) e a ambigüidade da organização (devido a freqüentes reorganizações). Assim, os autores conceitualizaram a ambigüidade em relação aos espaços vazios deixados pela incongruência de metas, pelas discordâncias sobre métodos ou explicações e pela mudança organizacional. Entretanto, enquanto March e Olsen teorizavam a ambigüidade como parte da explicação para os limites da racionalidade em processos de escolha organizacional, a metáfora do jazz nos encoraja a reinterpretar esses espaços vazios como oportunidades para a improvisação.

De forma interessante, em sua discussão sobre ambigüidade e escolhas em organizações, March (1976, p. 76-78) descreveu a execução, não no sentido musical, mas sim como uma "estratégia para suspender imperativos racionais em direção à consistência", o que serve à finalidade de ajudar as organizações a descobrirem novas metas. Para March (1976, p. 77), "a ludicidade permite a experimentação", e explica:

"Uma insistência rigorosa em relação a finalidades, consistência e racionalidade limita nossa habilidade de encontrar novas finalidades. $\mathrm{O}$ aspecto lúdico relaxa essa insistência para permitir agirmos de forma "nãointeligente', ou irracional, ou 'tola', para explorar idéias alternativas de finalidades possíveis e conceitos alternativos de consistência comportamental."

Quando as idéias de March sobre ludicidade são relacionadas à execução musical da metáfora do jazz, duas idéias são sugeridas. Primeiro, March esclarece que a metáfora do jazz pode oferecer pelo menos uma contribuição à nossa redescrição da estrutura organizacional em sua execução lúdica, a versão inspirada no jazz oferece um caminho direcionado para a criatividade na definição de novas finalidades e metas organizacionais. A metáfora do jazz, por sua vez, oferece a imaginação para apresentar maneiras de explorar finalidades alternativas ao longo das linhas da improvisação, ou seja, submetendo as idéias ao solo, ao acompanhamento, ao trading fours, à pergunta e resposta. Além disso, por meio de sua ênfase no engajamento corporal e sensório, a metáfora do jazz sugere como a improvisação na tomada de decisões organizacionais pode ocorrer além de uma forma puramente intelectual, racional. Uma boa tomada de decisões no que diz respeito à definição de novas finalidades e metas organizacionais, tal qual uma boa performance de jazz, irá requerer groove e sensibilidade.

As idéias de March sobre as relações entre a ludicidade e a definição de novas metas para organizações apresenta o problema do uso estratégico da ambigüidade. Eisenberg (1984) referiu-se a esse problema descrevendo os benefícios da ambigüidade estratégica em termos do que ele denominou diversidade unificada. Eisenberg (1984, p. 230) afirmou que as pessoas nas organizações nem sempre promovem a correspondên- cia entre suas intenções e as interpretações dadas às sua mensagens. Em alguns momentos, elas propositadamente omitem dicas contextuais para permitir múltiplas interpretações. Desse ponto de vista, as estruturas organizacionais são pelo menos particularmente definidas em termos de tensões (entre centralização e descentralização), e a ambigüidade ajuda a formar e a manter essas tensões permitindo "múltiplas interpretações ao mesmo tempo em que promove um senso de unidade". A tarefa dos líderes, na visão de Eisenberg, é encontrar "um nível de abstração no qual pode ocorrer um consenso", onde a ambigüidade "promove um consenso no que se refere a abstrações sem limitar interpretações específicas" (1984, p. 231). Imai et al. (1988) dão vários exemplos da utilização estratégica da ambigüidade no gerenciamento de equipes de desenvolvimento de novos produtos em empresas japonesas, como no caso do desenvolvimento do modelo City, da Honda. Nesse caso, Imai et al. (1988, p. 528) descrevem, os gerentes somente instruíram a equipe de jovens designers "a criar um conceito radicalmente diferente daquilo que um carro deveria parecer" e a desenvolver "o tipo de carro que os jovens gostariam de dirigir".

\section{JAZZ SUGERE COMO A} IMPROVISAÇÃO NA TOMADA

\section{DE DECISÕES ORGANIZACIONAIS}

\section{PODE OCORRER ALÉM DE}

\author{
UMA FORMA PURAMENTE \\ INTELECTUAL, RACIONAL.
}

A análise de Eisenberg da ambigüidade estratégica em organizações é similar ao caso dos jazzistas, em que cada um faz suas contribuições distintivas com base em suas interpretações e idéias, enquanto introduzem, ao mesmo tempo, referências suficientes à estrutura para permitir que seus esforços formem uma unidade, que é a composição. Entretanto, minha visão de ambigüidade na estrutura não é tão estratégica como na visão de Eisenberg, focada em como a ambigüidade atinge tanto unidade e diversidade, enfatizando as possibilidades inerentes em uma estrutura ambígua e a dupla função dessa estrutura para: (1) dar apoio a múltiplas e diversas contribuições e (2) fornecer unidade suficiente para dar apoio à interpretação das variadas contribuições de vários músicos em uma única composição ou, no caso das organizações, dar apoio à interpretação das contribuições de vários membros da organização em uma única performance. Essa visão é amparada pelo 
estudo de Meyerson (1991) sobre a ambigüidade na assistência social em hospitais.

Meyerson (1991) relaciona idéias sobre ambigüidade à cultura organizacional em seu estudo das experiências de assistentes sociais em hospitais, que descreveram sua rotina de trabalho normal como sendo altamente ambígua. Meyerson notou que, em sua amostra, assistentes sociais compartilhavam uma orientação e objetivos comuns, enfrentando problemas similares e com vivências comparáveis, mas essa cultura compartilhada acomodava variadas crenças e tecnologias, exigia soluções diferentes para problemas comuns e embasava significações múltiplas e por vezes conflitantes. Ela conclui que o desempenho eficiente da assistência social em hospitais dependia da aceitação e do uso da ambigüidade, que poderia ou não ter o apoio das culturas organizacionais às quais os assistentes sociais pertenciam, um apoio que resultaria em níveis mais baixos de exaustão psicológica.

Feldman (1991) ofereceu exemplos, baseados em estudos de caso, da teoria da ambigüidade organizacional de March e Olsen (1976). Em particular, os exemplos de Feldman de ambigüidade de intenção e de entendimento no Departamento de Energia americano apresentaram o lado negro da utilização estratégica da ambigüidade com a finalidade de manter a diversidade unificada, como defende Eisenberg. Por exemplo, ao mostrar como metas ambíguas e múltiplas interpretações conspiravam contra ações eficazes e minavam a auto-estima organizacional, Feldman sugeriu limites para as manobras estratégicas por meio de expressões ambíguas, limites que são negligenciados pela abordagem de Eisenberg, mais prescritiva. Assim, junto com o estudo de Meyerson, o trabalho de Feldman indica a importância de considerar o contexto cultural em estudos da ambigüidade de estruturas e práticas organizacionais.

A ambigüidade organizacional, no sentido mais amplo de apoio a múltiplas metas e interpretações, permite a manutenção das tensões organizacionais vitais, como a tensão entre a centralização e a descentralização. A aplicação da metáfora do jazz sugere como a ambigüidade da estrutura organizacional acomoda e pode até mesmo nutrir essas tensões. Os jazzistas reconhecem ambigüidades como espaços vazios nos quais eles podem inserir suas idéias e influenciar no modo em que uma composição estiver sendo executada em um dado momento. A ambigüidade permite aos músicos tocar as mesmas composições, mas simultaneamente personalizar e inovar cada composição tocada, a cada vez que eles a tocam. A ambigüidade nas estruturas organizacionais, vista desta forma, funciona de modo similar ao permitir que membros da organização revejam valores e competências organizacionais de maneiras personalizadas que ofereçam oportunidades para a criatividade e a inovação dentro de um contexto cultu- ral que provê coerência. Entretanto, lembremo-nos das advertências feitas por Meyerson e principalmente por Feldman: a interpretação dada ao uso estratégico da ambigüidade pode ser uma consideração importante; a ambigüidade vista como uma abertura para a improvisação (o caso do modelo City, da Honda, a cultura apoiadora do trabalho social) pode ser muito diferente em relação à ambigüidade interpretada como uma recusa do líder em assumir um solo quando deveria (os exemplos de Feldman no Departamento de Energia). Usar a ambigüidade de forma eficaz requer uma habilidade comprometida de ouvir e responder, como fica claro pela metáfora do jazz.

\section{A EMOCIONALIDADE DA ESTRUTURA}

Talvez o maior espaço vazio em nossas conceitualizações anteriores da organização venha sendo a emoção. Embora as estruturas sejam baseadas em relacionamentos humanos, gerentes e outros atores organizacionais têm freqüentemente tentado remover a emoção desses relacionamentos, sugerindo que emoções não são apropriadas ao ambiente de trabalho por interferir na tomada de decisões racional. Hopfl e Linstead (1997, p. 5) observam que as emoções são evitadas e desvalorizadas, no discurso organizacional, na sugestão de Weber que a eliminação do irracional e do emocional é uma das maiores contribuições da burocracia ao capitalismo. Apesar de o próprio Weber somente ter relatado que esse aspecto da burocracia foi interpretado como uma virtude (ele nunca disse por quem), seus escritos sobre a burocracia foram interpretados por gerentes e teóricos racionalistas da organização como pilares para sustentar o anti-emocionalismo. Entretanto, um número crescente de estudiosos e pesquisadores da organização acredita que temos sido muito pouco indulgentes no nosso entendimento dos aspectos emocionais dos relacionamentos organizacionais. (e.g. Hochschild, 1983; Rafaeli e Sutton, 1989; Albrow, 1992; Fineman, 1993; Ashforth e Humphrey, 1995). Esses pesquisadores fazem muitas referências ao valor e à função das emoções, por exemplo, nos processos de aprendizado e mudança e para os fins de desenvolvimento da cidadania, comprometimento e envolvimento organizacionais.

Poucos estudos sobre a emoção nas organizações examinaram questões estruturais, apesar de o altamente influente trabalho de Hochschild (1983) nesta área ter descrito o trabalho emocional em termos de "regras de sentimento". O estudo do jazz apresentado acima, entretanto, sugere um aspecto diferente da estrutura como emoção. Esse aspecto envolve pensar a estrutura organizacional em termos não de regras, mas de comunicação. Se emoções podem ser comunicadas, e há muitas evidências socio-psicológicas de que isso é pos- 
sível, então a emoção pode contribuir estruturalmente em organizações pela forma como os relacionamentos se organizam. Posto de outra forma, os sentimentos dos membros da organização os orientam uns em relação aos outros de maneiras particulares, e essas orientações são parte do que constitui a estrutura da organização como padrões de interações e relacionamentos. $\mathrm{O}$ posicionamento da estrutura no campo emocional reconhece os canais de comunicação freqüentemente ignorados que oferecem um complemento importante aos meios racionais de estruturação de relacionamentos organizacionais. Por exemplo, a importância da estruturação emocional em organizações fica clara no contexto do de-layering. Como influência e persuasão substituem a autoridade como meios para conseguir que as coisas sejam feitas em organizações de-layered, os relacionamentos passam de sua antiga dependência de racionalidade para bases emocionais, como atração interpessoal e amizade. Entretanto, a importância dos aspectos emocionais da estrutura é talvez ainda mais significativa no nível das interações do que no nível dos relacionamentos. Isso seria particularmente verdadeiro para organizações que dependem da constante reconfiguração de equipes de projeto ou que favorecem alianças temporárias, redes ou outras novas formas de organização, altamente flexíveis.

A metáfora do jazz sugere que, sempre que interagimos, a comunicação implica tanto sentimentos emocionais e sensações físicas quanto o conteúdo emocional das mensagens envolvidas. Comecei a ver a estrutura em termos emocionais quando tentei imaginar o equivalente emocional do groove e da sensibilidade na música. Groove e sensibilidade em termos de jazz envolvem fazer dos aspectos estruturais de uma performance (andamento e ritmo) implícitos, o que os jazzistas conseguem pela entrega às suas emoções e aos seus corpos. Assim como os jazzistas transportam o andamento e o ritmo para o campo do emocional e comunicam-se uns com os outros nesses termos, à medida que improvisam (mesmo quando eles nunca tocaram juntos antes), os trabalhadores podem depender de sua habilidade de se comunicar emocionalmente quando coordenam seus esforços para realizações organizacionais no contexto de equipes temporárias ou redes fluidas. Nesse sentido, Eisenberg (1990, p. 145146) fez a importante observação de que a comunicação emocional não depende necessariamente da autorevelação, mas é uma intimidade baseada em ações compartilhadas. Isto é, nós somos tão capazes de usar nossas emoções para formar relacionamentos de trabalho quanto somos capazes de usá-las para formar amizades ou relacionamentos familiares, e essa capacidade pode se estender àqueles com quem não temos nenhuma relação além da oportunidade de atuarmos juntos em um momento específico.
A relação com a ação nos traz mais uma vez ao tema dos aspectos performativos do jazz. De acordo com Csikszentmihalyi (1990), o auge do desempenho em vários campos de empreendimento, incluindo atletismo e música, é acompanhado por um estado subjetivo de fluxo no qual os atores experimentam absorção no momento, perdem o sentido de si e da situação e atingem um desempenho sem esforço. As descrições de fluxo feitas por Csikszentmihalyi lembram-me das discussões dos jazzistas sobre ritmo e harmonia, groove e sensibilidade, não somente como características materiais do jazz, mas como algo que os músicos internalizam e incorporam no contexto de tocar uma composição. Ritmo, harmonia, groove e sensibilidade possuem dimensões emocionais e estéticas e, quando esses aspectos dos processos de trabalho são relacionados, podemos, da mesma forma, encontrar a experiência do fluxo que Csikszentmihalyi afirma constituir o auge do desempenho.

\section{A Estrutura nÃO É}

\section{SAGRADA PARA UM MÚSICO DE JAZZ, MAS É UTILIZADA} PARA SUA PRÓPRIA ALTERAÇÃO.

A metáfora do jazz ainda mostra que o fluxo pode ser comunicado entre aqueles que trabalham juntos. Do mesmo modo que o ritmo, a harmonia, o groove e a sensibilidade criam uma comunhão entre músicos, platéia e vivência musical, o fluxo permite que uma forma emocional de comunicação ocorra entre colegas de trabalho (isso poderia ser parte daquilo a que Gersick (1994) fez referência por meio de seu conceito de "entrainment", apesar de não discuti-lo explicitamente em termos de emoção ou fluxo). Em outras palavras, a apreciação do groove e da sensibilidade em processos de trabalho pode harmonizar corpos em um ritmo comunal de trabalho que contribui para o auge do desempenho colaborativo.

Se os processos de trabalho têm ritmo, harmonia, groove e sensibilidade, então a metáfora do jazz sugere o desenvolvimento da sensibilidade emocional e corporal ao trabalho. Um dos locais em que poderíamos procurar evidências da efetividade de tal estratégia são os programas de desenvolvimento ao ar livre, nos quais muitas organizações investiram tempo e dinheiro consideráveis (Dainty e Lucas, 1992). Tais programas (como por exemplo a unidade de desenvolvimento corporativo da Outward Bound) alegam tornar os membros organizacionais mais conscientes das dimensões físicas e emocionais do trabalho que eles desempenham 
em suas organizações. As contribuições de tais programas podem ser, talvez, mais bem entendidas com a utilização de conceitos como ritmo, harmonia, groove e sensibilidade, que são ligados, pela metáfora do jazz, aos conceitos de entrainment e fluxo. Isto é, membros de uma equipe que estão em contato com seus corpos e suas emoções podem ser mais capazes de desenvolver ritmo, harmonia, groove e sensibilidade em seus processos de trabalho, o que irá melhorar a comunicação e o potencial colaborativo de sua equipe.

\section{A TEMPORALIDADE DA ESTRUTURA}

O tempo é um outro espaço vazio em nossa teoria organizacional recentemente exposto por um pequeno grupo de pesquisadores organizacionais e transformado em uma parte do vocabulário emergente dos estuda área. De acordo com esses pesquisadores (Jacques, 1982; Dubinskas, 1988; Gherardi e Strati, 1988; Hassard, 1991, 1996b), o problema do tempo em organizações é multifacetado e pode ser relacionado com fenômenos que variam de agendamento, eventos cíclicos e ciclos de desenvolvimento a histórias organizacionais, cenários para contemplar o futuro e visão corporativa. A maioria desses pesquisadores descrevem dois aspectos do tempo que considero serem particularmente relevantes à minha interpretação da metáfora do jazz para a estrutura organizacional: o andamento e o relacionamento entre passado, presente e futuro.

\section{ANDAMENTO}

Em sua introdução para a compilação de quatro etnografias enfocando os usos e significados do tempo em empresas de alta tecnologia, Dubinskas remeteu-se a Bourdieu (1977) para explicar a questão do andamento em relação à manipulação estratégica do tempo. Dubinskas (1988, p. 14) escreveu:

“(...) a definição do andamento, a expansão de fronteiras, o apressamento e atraso de agendas e a celebração de passagens. Essa manipulação artística do tempo é parte da reconstrução prática e intencional da ordem. A capacidade ou o poder de exercitar essa arte com maestria de maneira reconhecidamente padronizada mas não rigidamente limitada por regras é uma chave para o processo de construções de relações sociais eficazes."

Bourdieu (1977, p. 7) ofereceu vários exemplos de manipulação do andamento na organização estratégica da ação, incluindo:

“(...) atrasar ou adiar, manter o suspense ou a expectativa ou, por ouro lado, apressar, precipitar e surpreender, para não mencionar a arte de ostensivamente dar tempo ('reservar um tempo para alguém') ou reter o tempo ('sem tempo a perder')".

A manipulação estratégica do tempo no sentido de agendamento e monitoração do ritmo do trabalho é freqüentemente considerada como o domínio legítimo (e muito contestado) da gerência (tailorismo, fordismo). Todavia, como Gersick observou em seus estudos de projetos em grupo $(1988,1989)$ e de uma empresa aberta com base em capital de risco (1994), existe um padrão no ritmo de trabalho em equipes de projeto. Gersick relatou que os grupos por ela estudados trabalhavam lentamente até um ponto crítico correspondendo a cerca da metade do caminho ao longo de suas "vidas", após o qual, o ritmo aumentava em resposta a um crescente senso de urgência para cumprir um prazo explícito. Assim, em seu estudo, Gersick explicou o tempo em relação a metas e a prazos externamente impostos aos grupos observados por ela.

A metáfora do jazz fornece uma interpretação alternativa à explicação de Gersick do fenômeno da meiavida, sugerindo que diferentes processos de trabalho, tal qual diferentes composições de jazz, podem ter um andamento inerente e, quando tocados nesse andamento, eles "parecem certos". Em vez da mudança do andamento na metade de um projeto como afirmou Gersick, talvez a intensidade do envolvimento, como o crescendo que se cria perto do fim de uma composição de jazz bem tocada, altera a percepção interna do tempo, de forma que se tem a impressão de um ritmo mais acelerado.

A diferença na interpretação também é importante porque, se o andamento é uma característica da estrutura nas organizações, como na música, então alterá-lo pode levar a maiores dificuldades de coordenação. Um líder forte, naturalmente, tal qual um condutor de orquestra, pode orientar um grupo a alterar o andamento com grande eficácia. Entretanto, se um grupo estiver usando o andamento para se organizar tal qual uma banda de jazz faz, então o respeito ao andamento de um processo de trabalho pode ser crítico para atingir altos níveis de desempenho, por ser utilizado para coordenar atividades na ausência de uma função de liderança fixa. Talvez pelo próprio fato de estarem sintonizados com o andamento é que grupos como bandas de jazz são capazes de trocar de funções conforme necessário para atingir níveis máximos de desempenho. Em tais casos, em vez de uma performance orientada por um líder, o próprio andamento conduz a performance.

Anos de discussões sobre reduzir os lead times dos produtos deixaram a impressão em muitos gerentes de que processos podem ser "tocados" em qualquer andamento e que, quanto mais rápido, melhor. Isso reforça a imagem de líderes de projeto como condutores da execução ao longo das linhas do modelo orquestral. Por outro lado, se o que for necessário é a intensidade do envolvimento em vez da velocidade real, então a 
imagem da condução está errada. Diferentemente da urgência, que resulta de pressões externas, a intensidade vem de dentro, de forma que a influência sobre esta deve, da mesma forma, vir de dentro. Isso sugere que, pelo menos no que se refere à improvisação, membros de equipe (incluindo aquele que estiver na liderança em um dado momento) precisam ser conduzidos em vez de conduzir. Suas ações totalmente engajadas de pergunta e resposta ajudarão a fazer do desempenho do grupo uma ação conjunta, resultando em satisfações intrínsecas que proporcionarão maiores chances de atingir níveis máximos de desempenho.

Essa discussão indica um dos limites da metáfora do jazz. Apesar de alguns processos de trabalho serem mais bem definidos pela necessidade de interatividade e intensidade disciplinadas por uma batida ou um andamento uniformes, outros processos podem se adequar ao modelo orquestral de um líder forte conduzindo o andamento. O uso da metáfora do jazz em sua máxima capacidade requer a distinção entre situações que demandam criatividade ou flexibilidade e aquelas nas quais processos de trabalho bem aceitos simplesmente devem ser finalizados mais rapidamente. Quando criatividade ou flexibilidade são necessárias, a utilização das analogias à performance de jazz em relação a criar intensidade pode ser uma maneira proveitosa de se obter a transição do âmbito tradicional de liderança condutora focado em comunicar urgência e acelerar o ritmo.

No contexto da performance de uma composição de jazz, os músicos criam a intensidade a partir da estrutura de sua atuação. Eles geralmente começam com uma rodada de solos abertos, nos quais os membros trabalham algumas de suas idéias em relação ao tema e àquilo que os outros solistas e os que acompanham apresentaram até aquele momento específico. A rodada inicial de solos pode ser seguida por múltiplas rodadas de fours. Nesse ponto, a intensidade normalmente aumenta devido à rápida sucessão de solos e às ações mais entrelaçadas de pergunta e resposta necessárias aos músicos. Conforme a antecipação se cria em relação a quão bem os músicos estão interagindo com as idéias dos outros, a intensidade cresce até formar a parte final da composição - o fim.

Os finais envolvem todos os músicos tocando ao mesmo tempo, esperando-se que nesse momento eles estejam totalmente engajados em ouvir e responder, mas também remetendo-se às idéias formuladas em momentos anteriores na composição. A intensidade atinge o auge quando todas essas idéias são colocadas juntas, fazendo do final uma afirmação colaborativa que encontra sua conclusão na retomada do tema, mas, desta vez, o tema é tocado com tudo o que acabou de ser criado ainda pairando na memória, deixando, pelo menos em uma composição bem tocada, um senso de plenitude.

Observe dois pontos nessa noção de sobreposição para atingir um final. Primeiro, a sobreposição é o equivalente lingüístico de todos falando ao mesmo tempo, exceto que, no jazz, essa simultaneidade é sincronizada pela estrutura desenvolvida pela improvisação em torno de uma estrutura prévia. O equivalente organizacional seria todos trabalhando ao mesmo tempo de forma que idéias e habilidades se integram em um momento inten-

\section{Se o andamento é uma}

\section{CARACTERÍSTICA DA ESTRUTURA}

\section{NAS ORGANIZAÇÕES, COMO}

\section{NA MÚSICA, ENTÃO ALTERÁ-LO}

\section{PODE LEVAR A MAIORES \\ DIFICULDADES DE COORDENAÇÃO.}

so de interação que tem o potencial de informar e inspirar cada participante, de formas diversas, ainda que sincronizadas. Neste ponto, o espaço torna-se uma consideração que leva a pensar se a sincronicidade pode ser obtida quando os atores estão separados por distâncias físicas. Além de uma visão do tempo como um ponto no qual a performance pode ser feita em grupo (isto é, o final), um segundo aspecto do tempo sugere que o presente pode se estender além do passado, alcançar o futuro ou, em outras palavras, ligar o passado e o futuro. Essa idéia pode ser vista acima na descrição do estado ambíguo do tema tocado, como sendo, ao mesmo tempo, o início e o final de uma composição. No que se refere a isso, note em particular como os finais levantam as expectativas de tocar essa (ou uma outra) composição terminando pelo começo.

\section{PASSADO, PRESENTE E FUTURO}

Como foi descrito acima, a execução de temas no jazz proporciona tanto um ponto de partida como um ponto a ser retomado, possibilitando a criação de um final que leve o início em consideração. Gherardi e Strati (1988, p. 159) vislumbram um aspecto similar do tempo organizacional como "a atividade dos próprios atores organizacionais, que vêem eventos-chave como sendo ligados por um começo e por um fim". Os pontos estruturados do começo e do fim fornecem uma referência de onde estivemos em um passado histórico, mas também serve como pontos de impulso que nos levam ao futuro, quando a performance presente será parte da história. Assim, para os jazzistas, tocar uma composição é o ponto de ligação entre o passado, o presente 
e o futuro, da mesma forma que o tema de uma composição é o ponto de ligação entre seu início e seu fim.

Na performance, no presente estrito de tocar um jazz, o passado não passou, simplesmente. Ele é re-tocado e, assim, restabelecido no presente pelos músicos e membros da platéia. Por exemplo, aquelas composições que são tocadas com mais freqüência encerram uma memória coletiva que os jazzistas têm em comum, conhecida como jazz standards (como "God bless the child", de Billie Holiday, "Take the a-train", de Duke Ellington, "Round midnight", de Thelonius Monk, "Garota de ipanema", de Tom Jobim, "All blues", de Miles Davis, "Spain", de Chick Corea). Tocar o tema de um jazz standard pode evocar memórias que ligam o passado e o presente tanto para os músicos como para sua platéia. A citação, na qual jazzistas tocam solos, frases ou estilos famosos, associados a outros músicos (muitas vezes mais famosos), da mesma forma liga o passado ao presente. Tocar temas e citações é uma prática que permite aos músicos incorporar as idéias daqueles que influenciaram o jazz, mas que não estão presentes no palco. Essas idéias e memórias enriquecem o momento presente e impregnam esse momento com as forças emocionalmente atrativas do reconhecimento e da continuidade com o passado. Note, entretanto, como memórias diferentes de uma composição específica são colocadas juntas no instante da execução nesse tempo. As memórias específicas evocadas são moldadas pelas possibilidades apresentadas por esses músicos e essa platéia no momento presente.

Da mesma forma como o passado é evocado pela execução de um tema, também o é a antecipação da improvisação que se seguirá. Assim, o futuro é convidado ao presente por meio da expectativa criada pela lembrança de experiências similares no passado. Essas expectativas e recordações de músicos e membros da platéia preenchem a atividade da performance como uma junção do tempo passado e do tempo futuro, da memória e da antecipação. Assim, o passado e o futuro fundem-se em sua influência no presente, ocasionada pela performance de composições em uma celebração do que Ricoeur (1984, p. 9, citando Augustine) referiu-se como o presente tripartido (isto é, o presente do passado, o presente do presente e o presente do futuro). Assim, associações a uma composição espalham-se no tempo passado e são levadas adiante em sua ligação com o "presente do presente", para tomar de empréstimo a expressão de Ricoeur. Ademais, a antecipação disso pode trazer o tempo futuro para o momento presente, quando pode criar expectativas e ampliar a intensidade.

Em uma visão temporalmente sensível da estrutura organizacional, a dialética do passado, presente e futuro tem a mesma força. Conforme as organizações atuam, suas memórias (institucionalizadas nos produtos, normas e costumes da cultura organizacional) são evocadas por práticas culturais como contar histórias, fazer piadas ou quaisquer outras formas de manipulação simbólica de maneira muito similar a que as memórias atravessam a execução de uma composição por um músico de jazz quando performances passadas são evocadas por meio da execução de temas ou do uso de citações. Da mesma forma, as memórias do passado da organização imbuem as atenções presentes e, assim, moldam o futuro pela sua capacidade de estimular expectativas e antecipações que promovem a influência sobre a atenção, criando, dessa maneira, uma junção do passado e do futuro em um presente em três partes.

Para retornar mais uma vez ao tema da performan$c e$, se a experiência passada é interpretada como um suporte à expectativa do desempenho máximo, as chances de o auge da performance ocorrer são intensificadas. Evocar ocasiões passadas quando tal realização foi atingida nos lembra desse potencial e, assim, tem uma função motivacional ou inspiracional. $\mathrm{Se}$ as expectativas fossem negativas, naturalmente isso teria um efeito desanimador. De qualquer forma, memórias carregadas de emoção provavelmente provocarão a expectativa. Tais conexões são muitas vezes interpretadas em termos simplistas, sugerindo a muitos gerentes uma imagem de liderança similar ao do chefe de torcida. A metáfora do jazz sugere o reconhecimento de como as memórias e as expectativas dos atores organizacionais se cruzam em um dado momento para estruturar as dimensões emocionais e temporais do trabalho e da organização de maneira a influenciar a ação. Se alguém desejar exercer influência sobre os resultados organizacionais, a metáfora do jazz sugere que essa pessoa deve se inserir no processo, o que significa um envolvimento direto no presente em três partes da atuação. Somente por meio do envolvimento pessoal pode-se ativar a hermenêutica da memória, da atenção e da expectativa e, mesmo assim, a influência provavelmente se dará somente em proporção ao nível de envolvimento emocional/estético. Note como uma liderança desengajada não impede que o processo ocorra, isso somente localiza o processo em termos de um conjunto de atores que estão emocional e esteticamente desvinculados daqueles que desejam influenciá-los.

\section{RESUMO}

Em resumo, a estrutura é temporal no sentido que possui um andamento e ocorre com o tempo, mas também no sentido de constituir experiências temporais na junção do passado, do presente e do futuro em um presente em três partes. Por meio da recordação, a estrutura evoca ligações emocionais no passado, que, em antecipação, pode lançar âncoras emocionais no futu- 
ro, provocando tanto expectativas em relação ao presente momento quanto a sua intensidade. Entretanto, as significações e experiências evocadas pela temporalidade e emocionalidade da estrutura são eternamente ambíguas, envoltas no mistério dos espaços vazios que continuamente apresentam novas oportunidades para mudanças estruturais pelo envolvimento na atuação. Assim, encontramos somente uma dentre uma miríade de formas de descrever a estrutura como sendo simultaneamente ambígua, emocional e temporal, com o uso da metáfora do jazz.

\section{CONCLUSÃO}

O motivo pelo qual explorei a metáfora do jazz neste artigo foi investigar o potencial de redescrição que Rorty (1989) defendeu a favor da abordagem metafórica. A razão pela qual escolhi a metáfora do jazz foi parcialmente pela sua estranheza no discurso da estrutura (que, segundo Rorty, é essencial para a redescrição) e parcialmente pela sua riqueza, que associei com uma variedade de aspectos da organização surgindo no discurso emergente dos estudos organizacionais (especialmente a ambigüidade, a emocionalidade e a temporalidade). No desenvolvimento da redescrição, segui o conselho de Rorty, no sentido de não tentar lutar contra o vocabulário antigo, mas sim aliar-me com um novo. Entretanto, este é o momento de quebrar o silêncio entre a redescrição e o "vocabulário antigo", já que alguns leitores podem estar curiosos quanto ao benéfico da abordagem metafórica em relação a outras recentes reconceitualizações da estrutura organizacional, especialmente aquelas oferecidas por Giddens e seus seguidores.

Primeiramente, deixe-me reiterar que o benefício que se reivindica da redescrição metafórica é que, por meio dela, fica mais fácil escapar das garras dos vocabulários desgastados. Outras abordagens de reconceitualização da estrutura organizacional, por se manterem entrincheiradas nas velhas metáforas, como as metáforas da máquina, do organismo e do sistema, não oferecem uma possibilidade similar de construir um novo vocabulários nos termos de Rorty. Justamente por isso, não pretendo sacralizar a metáfora do jazz. Esse artifício foi útil ao me auxiliar a reconceitualizar a estrutura organizacional em termos compatíveis com o vocabulário emergente dos estudos organizacionais, e é nesses termos que o ofereço aos leitores. É o processo de redescrição que importa, não a metáfora em si. De fato, se a metáfora do jazz for bem-sucedida, também ela precisará ser substituída, já que, com o tempo, ela se tornará literal ao invés de metafórica, como explicado por Davidson (1984), e perderá seu poder de informar e de inspirar.

Alguns poderão argumentar que tudo o que foi dito aqui sobre estrutura organizacional pode ser dito (ou até foi dito) por aqueles menos dispostos a se livrar dos vocabulários antigos. Suspeito que os que dizem isso estejam apropriando-se do que ofereço para lançálo de volta ao vocabulário antigo. Para ser o mais precisa possível, não vejo em reconceitualizações anteriores da estrutura organizacional as dimensões emocional e estética da estrutura enfatizadas pela metáfora do jazz. Pode-se dizer que essas dimensões estão presentes em todas as conceitualizações de uma forma latente, mas minha resposta é que a abordagem metafórica funciona no sentido de anular essa latência.

\section{AS MEMÓRIAS DO PASSADO}

\section{DA ORGANIZAÇÃO IMBUEM AS}

\section{ATENÇÕES PRESENTES E, ASSIM, MOLDAM O FUTURO PELA SUA}

\section{CAPACIDADE DE ESTIMULAR}

\section{EXPECTATIVAS E ANTECIPAÇÕES.}

Minha visão é que existem fronteiras de vivência que a linguagem literal menos figurativa da ciência não pode cruzar com facilidade. A abordagem metafórica penetra nessas fronteiras. Assim, alego que a contribuição deste artigo é que a natureza metafórica do método empregado contribui com algo único. No caso específico da metáfora do jazz, ela contribui com imaginação para o conceito redescrito de forma que nos ajuda a ouvir, sentir e nos engajar com nossas estruturas organizacionais, em vez de simplesmente pensar sobre elas. Alego que esse elemento de apreciação está ausente nas tentativas anteriores de reconceitualizar a estrutura organizacional e que, desta forma, a abordagem metafórica contribui com um valor distintivo (apesar de a metáfora do jazz não contribuir necessariamente com mais valor do que as outras metáforas). Meu argumento é que precisamos ir além da reconceitualização - ou talvez aquém - para redescrever a estrutura organizacional como uma forma de nos relacionarmos com o novo vocabulário para a teorização organizacional que envolve a apreciação emocional e estética bem como o rigor analítico.

Seguindo a prática do jazz, retorno agora ao meu ponto de partida e reafirmar minha observação de que a própria estrutura organizacional se tornou uma ausência em nosso discurso. $\mathrm{O}$ movimento que fiz em recuperar o conceito pela redescrição metafórica é uma continuação do movimento que levou ao seu abandono em primeiro lugar, isto é, o movimento de fazer e preencher os espa- 
ços vazios. Este artigo não pretende colocar um fim a esse processo de fazer e preencher os espaços vazios, mas sim celebrá-lo para engajar no discurso sempre emergente dos estudos organizacionais. Assim, a proposta deste texto não foi fazer algo que nunca foi feito antes, mas sim fazer algo que vale a pena ser feito de novo. Seu propósito é combinar passado e presente para encontrar expressões de identidade e de ser que não são meras repetições do passado, mas que continuamente reinventam o presente em relação tanto ao passado quanto ao futuro. A redescrição é uma importante parte deste processo sem fim, e o desenvolvimento da metáfora do jazz neste artigo é minha contribuição para esta aventura.

A metáfora do jazz, tal qual qualquer outra abordagem metafórica, tem suas limitações. Ao desenvolver e aplicar uma metáfora, é fácil ficar tão envolvido nas similaridades entre o veículo e o alvo que as diferenças são ignoradas. Há certamente aspectos da estrutura organizacional que são ignorados pela metáfora do jazz. O mais claro aspecto, como foi apontado anteriormente, é que muitos elementos da organização são rotineiros e não requerem improvisação. Nesse ponto, talvez uma outra metáfora (por exemplo a condução de orquestras) poderia ser mais proveitosa. A análise oferecida neste artigo sugere que metáfora do jazz pode ser a mais adequada a situações que demandam criatividade e flexibilidade, nas quais a improvisação é um benefício ao desempenho.

Peço ao leitor que tenha em mente que eu não ofereço a metáfora do jazz como uma nova metáfora-raiz para o campo dos estudos organizacionais. Ela é, nos termos de Rorty, somente uma "teoria passageira", uma ferramenta para manter o pensamento em movimento, mas se movendo de uma forma adequada aos nossos propósitos e imaginações somente temporariamente. Acredito que esta seja somente uma dentre uma variedade de oportunidades metafóricas. O que interessa é o que fazemos com nossas metáforas, como Rorty (1989) e Davidson (1984), dentre outros, explicaram. Neste caso, usei a metáfora do jazz para trazer à tona os aspectos temporal, emocional e ambíguo da estrutura organizacional como um conceito para orientar tanto o pensamento quanto a organização. Entretanto, outras metáforas em outros momentos e lugares têm o mesmo ou mais valor.

Enfim, meu desenvolvimento da metáfora do jazz é mais uma demonstração da redescrição de Rorty (1989) do que o oferecimento de uma nova metáfora para os estudos organizacionais, mas, além disso, o artigo se engaja nas práticas que descreve. Nesse sentido, foram feitos solos e acompanhamento, um dar e receber entre as idéias que tentei expressar e as idéias tomadas do vocabulário emergente dos estudos organizacionais. Além disso, esta composição já foi tocada antes, e esta forma de ver as coisas contém referências às respostas de platéias anteriores (sugestões de revisores e comentários daqueles que participaram de conversas comigo sobre a metáfora do jazz) na forma de minhas respostas às suas respostas, que estão ao longo de todo este texto. Leituras sucessivas podem continuar esse processo à exaustão. Entretanto, a cada vez que o artigo é lido, se eu atingir minha ambição de ter o leitor ouvindo e respondendo, então haverá a chance de desenvolver um groove e uma sensibilidade que nos permitirão uma comunicação além dos canais intelectuais normais pelo engajamento em dimensões emocionais e estéticas de nosso ser. Esse é, para mim, o local em que o valor desta redescrição metafórica pode ser encontrado.

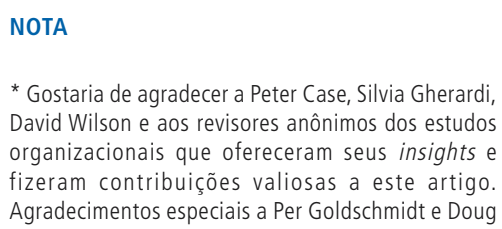

* Gostaria de agradecer a Peter Case, Silvia Gherardi, David Wilson e aos revisores anônimos dos estudos organizacionais que ofereceram seus insights e fizeram contribuições valiosas a este artigo. Agradecimentos especiais a Per Goldschmidt e Doug

REFERÊNCIAS BIBLIOGRÁFICAS

ADAMS, J. L. Conceptual blockbusting: a guide to better ideas. 3. ed. Reading, MA : Addison Wesley, 1990.

ALBROW, M. Sine ire et studio or: do organizations have feelings?. Organization Studies, v. 13, n. 3, p.313-330, 1992.

ALVESSON, M. Organization: from substance to image. Organization Studies, v. 11, n. 3, p. 373-394, 1990.
Conner por seu desenvolvimento paciente do meu entendimento e da minha apreciação do jazz e pela inspiração que encontrei em sua música.

Artigo traduzido para o Português, publicado originalmente na Organization Studies, V. 20, p. 75100, Berlin : 1999. Walter de Gruyter \& Company, 1999.

(C) Walter de Gruyter \& Company 1999. 0 autor expressa-Ihes toda sua gratidão.
ASHFORTH, B. HUMPHREY, R. Emotion in the workplace: a reappraisal. Human Relations, v. 48, n. 2, p. 97-126, 1995.

BARRETT, F. Creativity and improvisation in jazz and organizations: implications for organizational learning. Organization Science, v. 9, n. 5, p. 605-622, s.d.
BASTIEN, D. T., HOSTAGER, T. J. Jazz as a process of organizational innovation. Communication Research, n. 15, p. 582-602, 1988.

BASTIEN, D. T., HOSTAGER, T. J. Cooperation as communicative accomplishment: a symbolic interaction analysis of an improvised jazz concert. Communication Studies, n. 43, p. 92-104, Summer, 1992. 


\section{REFERÊNCIAS BIBLIOGRÁFICAS}

BERLINER, P. F. Thinking in jazz: the infinite art of improvisation. Chicago : University of Chicago Press, 1994.

BODEN, D. The business of talk: organizations in action. Cambridge : Polity Press, 1994

BOJE, D. M., GEPHART, R. P. Jr., THATCHENKERY, T. J. (Eds.) Postmodern management and organization theory. Thousand Oaks : Sage, 1996.

BOURDIEU, P. Outline of a theory of practice. Cambridge: Cambridge University Press, 1977.

BURRELL, G. Pandemonium: towards a retro organization theory. London: Sage, 1997.

COOPER, R., BURRELL, G. Modernism, postmodernism, and organizational analysis: an introduction. Organization Studies, v. 9, n. 1, p. 91112, 1988.

CROSSAN, M., SORRENTI, M. Making sense of improvisation. Advances in Strategic Management, v. 14, p. 155-180, 1997.

CSIKSZENTMIHALYI, M. Flow: the psychology of optimal experience. New York: Harper and Row, 1990.

DAINTY, P., LUCAS, D. Clarifying the confusion: a practical framework for evaluating outdoor development programmes for managers. Management Education and Development, v. 22, n. 2, p. 106-122, 1992.

DAVIDSON, D. What metaphors mean. In: DAVIDSON, D. Inquiries into truth and interpretation. Oxford: Oxford University Press, 1984. p. 245-264.

DUBINSKAS, F. A. (Ed.) Making time: ethnographies of high-technology organizations. Philadelphia: Temple University Press, 1988.

EISENBERG, E. M. Ambiguity as strategy in organizational communication. Communication Monographs, n. 51, p. 237-242, 1984.

EISENBERG, E. M. Jamming: transcendence through organizing. Communication Research, v. 17, n. 2, p. 139-164, 1990.

FELDMAN, M. The meanings of ambiguity: learning from stories and metaphors. In: FROST, P. J. et al. (Eds.). Reframing organizational culture. Newbury Park: Sage, 1991. p. 145-156.

FINEMAN, S. (Ed.) Emotion in organizations. London : Sage, 1993.

GAGLIARDI, P. Artifacts and pathways and remains of organizational life. In: GAGLIARDI, (Ed.) Symbols and artifacts: views of the corporate landscape. New York: Aldine de Gruyter, 1990. p. 3-38.

GAGLIARDI, P. Exploring the aesthetic side of organizational life. In: CLEGG, S. R., HARDY, C., NORD, W. R. (Eds.) Handbook of organization studies. London: Sage, 1996. p. 565-580.
GERGEN, K. Organization theory in the postmodern era. In: REED, M., HUGHES, M. (Eds.) Rethinking organizations: new directions in organization theory and analysis. London: Sage, 1992. p. 209-226.

GERSICK, C. Time and transition in work teams: toward a new model of group development. Academy of Management Journal, n. 31, p. 9-41, 1988.

GERSICK, C. Marking time: predictable transitions in task groups. Academy of Management Journal, n. 32, p. 274-309, 1989.

GERSICK, C. Pacing strategic change: the case of a new venture. Academy of Management Journal, n. 37, p. 945, 1994.

GHERARDI, S., STRATI, A. The temporal dimension in organizational studies. Organization Studies, v. 9, n. 2, p. 149-164, 1988

GIDDENS, A. Central problems in social theory: action, structure and contradictions in social analysis. London : Macmillan, 1979.

GIDDENS, A. The constitution of society: outline of the theory of structuration. Berkeley: University of California Press, 1984

HASSARD, J. Aspects of time in organization. Human Relations, v. 44, n. 2, p. 105-125, 1991.

HASSARD, J. Exploring the terrain of modernism and postmodernism in organization theory. In: BOJE, D. M., GEPHART, R. P. THATCHENKERY, T. J. (Eds.) Postmodern management and organization theory. Thousand Oaks : Sage, 1996a. p. 45-59.

HASSARD, J. Images of time in work and organization. In: CLEGG, S. R., HARDY, C., NORD, W. R. (Eds.) Handbook of organization studies. London : Sage. 1996b. p. 581-598.

HASSARD, J., PARKER, M. Postmodernism and organizations. London : Sage, 1993.

HATCH, M. J. The dynamics of organizational culture. Academy of Management Review, v. 18, n. 4, p. 657 693, 1993.

HATCH, M. J. Jazzing up the theory of organizational improvisation. Advances in Strategic Management, $\mathrm{n}$. 14, v. 181-191, 1997.

HATCH, M. J., SCHULTZ, M. Relations between organizational culture, identity and image. European Journal of Marketing, n. 31, p. 356-365, 1997.

HESSE, M. The explanatory function of metaphor. In: HESSE, M. Revolutions and reconstructions in the philosophy of science. Bloomington : Indiana University Press, 1980.

HOCHSCHILD, A. R. The managed heart. Berkeley University of California Press, 1983.

HOPFL, H., LINSTEAD, S. Learning to feel and feeling to learn: emotion and learning in organizations. Management Learning, n. 28, p. 5-12, 1997.

IMAI, K., NONAKA, I., TAKEUCHI, H. Managing the new product development process: how Japanese companies learn and unlearn. In: TUSHMAN, M. L., MOORE, W. L. (Eds.) Readings in the management of innovation. 2. ed. Cambridge : Ballinger, 1988. p. 337-381.
JACQUES, E. The form of time. New York: Crane Russak, 1982

MARCH, J. G. The technology of foolishness. In: MARCH, J. G., OLSEN, J. P. (Eds.) Ambiguity and choice in organizations. Bergen : Universitetsforlaget, 1976. p. 69-81.

MARCH, J. G., OLSEN, J. P. Organizational choice under ambiguity. In: MARCH, J. G., OLSEN, J. P. (Eds.) Ambiguity and choice in organizations. Bergen : Universitetsforlaget, 1976. p. 10-23.

MEYERSON, D. "Normal" ambiguity? In: FROST, P. J. et al. (Eds.) Reframing organizational culture. Newbury Park: Sage, 1991. p. 131-144.

MINTZBERG, H., RAISINGHANI, D., THEORET, A. The structure of unstructured decision processes. Administrative Science Quarterly, n. 21, p. 246-275, 1976.

MORGAN, G. Images of organization. Newbury Park : Sage, 1986.

PETTIGREW, A. M. Context and action in the transformation of the firm. Journal of Management Studies, n. 24, p. 649-670, 1987.

PETTIGREW, A. M., WHIPP, R. Managing change for competitive success. Oxford: Basil Blackwell, 1991.

RAFAELI, A., SUTTON, R. The expression of emotion in organizational life. In: CUMMINGS, L. L., STAW, B. M. (Eds.) Research in organizational behavior. v. 11. n. 142. Greenwich : JAI Press, 1989.

RANSON, S. HININGS, GREENWOOD, R. The structuring of organizational structures. Administrative Science Quarterly, n. 25, p. 1-17, 1980.

REED, M. I. In praise of duality and dualism: rethinking agency and structure in organizational analysis. Organization Studies, v. 18, n. 1, p. 21-42, 1997.

REED, M. I., HUGHES, M. (Eds.) Rethinking organizations: new directions in organization theory and analysis. London : Sage, 1992.

RICOEUR, P. Time and narrative. v. 1. Chicago : University of Chicago Press, 1984.

RORTY, R. Contingency, irony and solidarity. New York: Cambridge University Press, 1989.

SCHULTZ, M. Postmodern pictures of organizational culture. International Studies of Management and Organization IS-35, Summer, 1992.

WEICK, K. E. Organized improvisation: 20 years of organizing. Communication Studies, n. 40, p. 241248, 1989.

WEICK, K. E. Organizational redesign as improvisation. In: HUBER, G. P. GLICK, W. H. (Eds.) Organizational change and redesign: ideas and insights for improving performance. New York : Oxford University Press, 1993. p. 346-379.

WEICK, K. E. Sensemaking in organizations. Newbury Park : Sage, 1995.

WEICK, K. E. Improvisation as a mindset for organizational analysis. Organization Science, v. 9, n. 5, p. 540-555, 1998. 